\title{
Knowledge and practice of blood donation among national youth corp members in orientation camp Sagamu Ogun State.
}

\author{
*Ojo O.T., Bello F., Adenuga J.O., Bakare B.Y., Kolade D.O., Olatunji P.O.
}

\begin{abstract}
Asbtarct
Onjectives: Millions of lives are saved each year through blood transfusion, yet the availability, quality and the safety of blood transfusion is still a concern, particularly in the developing countries. The factors influencing blood donation vary and one's knowledge can influence this decision. To assess the factors influencing the knowledge and practice of blood donation among youth corp members in Ogun State, Nigeria.
\end{abstract}

Methods: A cross-sectional study of randomly selected 600 youth corp members. Data was collected through self- administered pretested structured questionnaires and analyzed with SPSS version 21. Multiple regression analyses were used to identify the significant predictors of knowledge and practice of blood donation, with statistical significance at $95 \%$ confidence interval.

Results: Knowledge of blood donation was adequate among 220 (41.5\%) of the respondents, $89(16.6 \%)$ had donated blood. Age younger than or equal to 24 years (AOR=2.040, 95\% CI:1.404,2.966) and studying health science courses (AOR $=10116,95 \% \mathrm{CI}: 4,368,427)$ were significant determinants of knowledge. Male gender, marital status, religion, course of study, medium of awareness and good knowledge of blood donation were significant determinants of blood donation among corp members. The commonest reason for donation was replacement $(48.3 \%)$ and most common reason for not donating was because of never been asked to donate $(53.6 \%)$. One hundred and sixty-three $(30.5 \%)$ signified that they would donate if asked.

Conclusion: Level of adequate knowledge about blood donation was low and those who had donated are in the minority. There is need to create more awareness on the importance of blood donation among the youth.

Keywords: blood donation, knowledge, youth corp members, practice

\author{
*Corresponding author \\ Ojo O.T. \\ http://orcid.org/0000-0002-7211-650X \\ Email: fiyinfola02@gmail.com
}

Dept. of Haematology \& Blood Transfusion, Olabisi Onabanjo University Teaching Hospital, Sagamu, Nigeria

Research Journal of Health Sciences subscribed to terms and conditions of Open Access publication. Articles are distributed under the terms of Creative Commons Licence (CC BY-NC-ND 4.0). (http://creativecommons.org/licences/by-nc-nd/4.0).

http://dx.doi.org/10.4314/rejhs.v7i3.7 


\title{
Connaissance et pratique du don de sang parmi les membres du groupe national de jeunes du camp d'orientation de l'État de Sagamu Ogun.
}

\author{
*Ojo O.T., Bello F., Adenuga J.O., Bakare B.Y., Kolade D.O., Olatunji P.O.
}

\begin{abstract}
Resume
Objectifs: Des millions de vies sont sauvées chaque année grâce à la transfusion sanguine. Cependant, la disponibilité, la qualité et la sécurité de la transfusion sanguine restent un sujet de préoccupation, en particulier dans les pays en développement. Les facteurs qui influencent le don de sang varient et les connaissances acquises peuvent influer sur cette décision. Évaluer les facteurs influant sur la connaissance et la pratique du don de sang chez les jeunes membres de la société dans l'État d'Ogun, au Nigéria.
\end{abstract}

Méthodes: Une étude transversale de 600 membres du groupe de jeunes sélectionnés au hasard. Les données ont été collectées au moyen de questionnaires structurés pré-testés auto-administrés et analysées avec SPSS version 21. Des analyses de régression multiple ont été utilisées pour identifier les prédicteurs significatifs de la connaissance et de la pratique du don de sang, avec une signification statistique à un intervalle de confiance de $95 \%$.

Résultats: La connaissance du don de sang était adéquate chez 220 (41,5\%) des répondants, dont 89 $(16,6 \%)$ avaient donné du sang. Les jeunes de moins de 24 ans (AOR = 2,040, IC 95\%: 1,404,2,966) et les cours en sciences de la santé (AOR = 10116, IC 95\%: 4368 427) étaient des déterminants importants du savoir. Le sexe masculin, l'état matrimonial, la religion, le programme d'études, le moyen de sensibilisation et une bonne connaissance du don de sang étaient des facteurs déterminants du don de sang parmi les membres du groupe. La raison la plus courante du don était le remplacement $(48,3 \%)$ et la raison la plus courante pour ne pas donner était due au fait que personne n'avait jamais été invité à faire un don $(53,6 \%)$. Cent soixante-trois $(30,5 \%)$ ont indiqué qu'ils feraient un don si on le leur demandait.

Conclusion: le niveau de connaissance du don de sang était faible et les donneurs étaient minoritaires. Il est nécessaire de sensibiliser davantage les jeunes à l'importance du don de sang.

Mots-clés: don de sang, connaissances, membres d'un groupe de jeunes, pratique

\author{
*Auteur principal \\ Ojo O.T. \\ http://orcid.org/0000-0002-7211-650X
}

Email: fiyinfola02@gmail.com

Dept. of Haematology \& Blood Transfusion, Olabisi Onabanjo University Teaching Hospital, Sagamu, Nigeria 


\section{INTRODUCTION}

Adequate and safe blood supply has remained a challenge in developing countries like Nigeria. World Health Organization Blood Donation Policy favors voluntary donation only, due to the higher likelihood of increased incidence of transfusion transmissible infections from paid donors $(1,2)$. There is a need to motivate young generations to meet $100 \%$ voluntary not-paid blood donation as WHO reported that $38 \%$ of voluntarily donated blood comes from young people aged less than 25 years (3). Hence the study target is to assess the knowledge and practice towards blood donation among youth corp members with the aim of recruiting them as voluntary non-remunerated blood donor.

\section{MATERIALS AND METHODS}

Study area: This study was carried out at the National Youth Service Corp Permanent Orientation Camp Sagamu, Ogun State, Nigeria. The National Youth Service Corp (NYSC) members are young, healthy and active people with age range usually between 20-30 years who recently completed academic programs at higher institutions of learning. They are posted annually to all the states in Nigeria. National Youth Service Corp Permanent Orientation Camp Sagamu is where all the youth corp members posted to serve the nation in Ogun State have orientation for a period of 2- 3 weeks on their line of activities for their one-year service of the father's land. There are usually three batches of youth corp members with two streams each, each stream usually contains between 1800 to 2200 members.

Study design: This was a cross sectional study in which 600 participants were selected by random sampling technique from youth corp members undergoing orientation at the orientation camp in Sagamu after obtaining approval from the Health Research Ethics Committee of Olabisi Onabanjo University Teaching Hospital (OOUTH), Sagamu. Sixty consenting participants were randomly selected from each platoon of 10 , each platoon had a minimum number of 180 . Information on the importance of blood donation was given after the self-administered pretested questionnaires have been completed.

Study population: This study was carried out among the first stream of the first batch of youth corp members for the year 2019 .

Data collection tools: The self-administered questionnaire was used to obtain demographic data (such as age, sex, religion, marital status, course of study) and contain questions regarding knowledge and practice of blood donation.

Data Analysis: The responses were analyzed with the Statistical Package for Social Sciences (SPSS) 21. The categorical data was summarized with frequencies and percentages, while the quantitative data was summarized with mean and standard deviation. Chi-square test was used to investigate association between categorical variables and $\mathrm{P}$-value of less than 0.05 was considered as significant. Multivariate analysis was employed to identify predictors of knowledge and practice of blood donation by considering Confidence Interval of $95 \%$. The results were presented in a narrative forms and tables.

\section{Operational definitions}

Knowledge: A score of one was given for the correct response and zero for wrong response. Respondents who scored above $50^{\text {th }}$ percentile of the total score were considered to have good knowledge and others were considered as having poor knowledge.

Practice: Denote when individuals experienced blood donation activity.

Course of study was grouped into 2: Health and Non-Health.

Health Sciences included Medical and B a s i c Medical Sciences

Non-Health Sciences included Art, education, Social Sciences, Sciences, Management, Engineering and Agriculture.

Medium of awareness of blood donation was grouped into 2: Health workers and others Others included Mass media (radio, television, social media and internet) and friends.

\section{RESULTS}

\section{Socio-demographic characteristics of the respondents}

Out of 600 participants' recruited 535 participants responded with response rate of $89.2 \%$. Their aged ranged from 19 to 29 with mean of $24.8 \pm 2.5$ years. Two hundred and seventy-six thousand $(51.6 \%)$ of the respondents were male while 259 (48.4\%) were female, giving a male to female ratio of 1.1:1. Majority, $521(97.4 \%)$ were single while $14(2.6 \%)$ of the respondents were married. Four and fifty-three were Christian while $82(15.3 \%)$ were Muslim. Four hundred and ninety $(91.6 \%)$ studied non- 
health related courses while $45(8.5 \%)$ studied health science related courses. Two hundred and ninety-seven $(53.5 \%)$ got information on blood donation from mass media and friends while source of awareness on blood donation in 238 $(44.5 \%)$ was from health workers.

\section{Knowledge of blood donation}

Two hundred and twenty-two (41.5\%) participants showed good knowledge and $313(58.5 \%)$ showed poor knowledge of blood donation. As shown in Table 1, more than half of the respondents know at least 1 importance of blood donation which is cancer in which $331(61.9 \%)$ answered correctly, however their knowledge about estimated blood volume per donation, duration of donation process and ideal donation frequency were below average which were $10.7 \%, 24.9 \%$, and $9.2 \%$ respectively. About half, 258(48.2\%), of them know that men should donate.Their Knowledge about other transmission transmissible infections( TTI's) apart from HIV which 476 (91.9\%) got correctly was far below average.

\section{Practice of blood donation}

Eighty-nine (16.6\%) had donated in the past while $446(83.4 \%)$ have never donated before. Among those that had donated in the past, $24(27 \%)$ donated thrice or more times annually while $65(73 \%)$ donated less three times annually. Majority, 43(48.3\%) were replacement donors whereas $33(37.1 \%)$ and $13(14.6 \%)$ donated because they wanted to do good and to get health counsel respectively. The major reason why the respondents who have never donated gave was that they have never been asked to donate blood, $239(53.6 \%)$ out of 446 . Other reasons included: inconvenience due to location and time in 57 $(12.8 \%)$, fear of needle in $56(12.6 \%)$, unfit to donate in $37(8.3 \%)$, religious belief in $7(1.6 \%)$, fear of knowing HIV status in $4(0.9 \%)$ and cultural belief in $3(0.7 \%)$. Forty- three $(9.5 \%)$ did not give a response. One hundred and sixtythree out of $535(30.5 \%)$ participants were willing to donate blood when reminded while 372 $(69.5 \%)$ were not willing even when called upon.

\section{Factors associated with the level of knowledge} Bivariate analysis showed that younger age group of $\leq 24$ years was significantly associated with good knowledge of blood donation $(\mathrm{P}=0.000)$. Also, the course of study has a significant association with level of knowledge, 38 out of $45(84.4 \%)$ respondents who studied health science related courses had good knowledge $(\mathrm{P}=0.000)$. Sex, marital status, religion and medium of awareness of blood donation did not impact significantly on the level of their knowledge (Table 2).

Multivariate logistic regression was used to identify factors associated with the level of knowledge on blood donation. Age group and course of study remained significant predictors of level of knowledge $(\mathrm{AOR}=2.040,95 \%$ $\mathrm{CI}: 1.404,2.966$ and $\mathrm{AOR}=10.116,95 \%$ CI:4,368,427 respectively). Those who were $\leq 24$ years were twice more likely to have a better knowledge than those $>24$ years. Those who studied health science course were 10 times more likely to have a better knowledge than those who studied non-health related courses (Table 4.)

\section{Factors associated with blood donation}

Bivariate analysis showed that variables such as older age group of $>24$ years, male, marriage, Islam, studying health science courses and awareness of blood donation through health workers were significantly associated with blood donation act as shown in Table $3(\mathrm{P}=0.041$, $0.000,0.0010 .000,0.001$ respectively).Bivariate analysis also showed that $50(56.2 \%)$ of those who had donated before had good knowledge while $172(38.6 \%)$ of those who have not donated before had poor knowledge $\left(\mathrm{X}^{2}=9.483, \mathrm{P}=0.002\right)$.

The associated factors were assessed for their impact on the act of donation using multivariate logistic regression. $\operatorname{Sex}(A O R=2.298,95 \%$ CI:1.353,3.904), marital status(AOR=0.208, 95\% CI:0.075,0.971), r e $1 \mathrm{i}$ g i o n ( A O R $=0.440,95 \%$ CI:0.247,0.785), course of study $(\mathrm{AOR}=3.144$, 95\% CI:1.477,6.694), source of awareness on blood donation( A R $=1.672,95 \%$ CI:1.026,2.725) and good knowledge of blood donation $(\mathrm{AOR}=2.141$, 95\% CI:1.279,3.582) remained significant while age group was influenced by other sociodemographic characteristics. Male were likely to donate 2.3 times more than female, singles were $79.2 \%$ less likely to donate than married, Christians were $56 \%$ less likely to donate than Muslim. Those that studied health science courses are 3 times likely to donate than those that did not study health science related courses. Those whose source of awareness of blood donation was health workers 1.6 times likely to donate blood than those who heard from other sources. Also, those with good knowledge were 2.1 times more likely to donate than those with poor knowledge (Table 5). 


\section{DISCUSSION}

Assessment of the level of knowledge and practice of blood donation with their associated factors play important roles in blood supply sustainability and safety. The overall level of good knowledge of $41.5 \%$ in this study is similar to $37.5 \%$ reported in India (4) but higher than $9 \%$ reported in Manipur (5). The level of knowledge in the index study is in contrast to $80 \%$ reported in a similar study in Thailand (6) and $83.6 \%$ from Addis Ababa (7). The difference might be due to educational background of the participants who were mainly medical student and healthcare professionals.

Age and course of study remained significant predictors of knowledge level after adjusting for all possible confounders. There was significant difference in the level of good knowledge among those whose age was less than 24 years. This was in contrast to study by AlAsadi et al where age was not found to be predictor of knowledge level (8). This might be due to inquisitiveness of younger age group. Also, the knowledge of those who studied heath science related courses was significantly better than those who studied non-health related courses. This might be due to impact of their exposure to health facility and their educational background.

The study revealed that $16.6 \%$ have donated among the participants, this is similar to reports of $15 \%, 18.7 \%, 18.1 \%$, from other studies $(9,10,11)$ but lower than $30 \%$ reported by Elias et al among university students in Tanzania (12). This could be due to high level of their willingness to donate as $88 \%$ were willing to donate in future in contrast to only $30.5 \%$ in this index study. The greatest motivating factor for blood donation was to save a friend or a family member in $48.3 \%$ of the respondents. This is in consonance with the study at the blood centre of Umee University Hospital, Sweden, where $47.2 \%$ of the respondents said their motivation for donating blood was to save a friend (13). This still shows that generally majority of donors are replacement donors. The most frequent reason given for not donating blood was not being asked to donate which is similar to report from other studies $(14,15)$. Inconvenience of location of blood bank and time, fear of needle and unfit to donate were some other common reasons given for not donating, all these align with findings from other studies $(16,17)$.

Studies have shown how blood donors differ from non-donors with respect to their specific socio-demographic characteristics, such as sex, age, marital status and levels of education $(18,19)$. Males were found to likely donate blood more than females which is similar to findings in other studies $(20,21)$. This may be due to erroneous belief that menstruation could make the haemoglobin of females inadequate for blood donation.

In this study those participants that were single were found to have less likelihood of donating blood. This might be due to likelihood of experience with situations that required blood transfusion in their spouse or children which gave them high sense of responsibility and empathy. This is corroborated by Burgdof et al, who reported that the prevalence of blood donation was considerably lower among men living with their parents $(2.9 \%)$ or alone $(3.9 \%)$ than among men cohabitating with a woman $(6.2 \%)(22)$.

Psychosocial studies have shown that religious affiliation has vital effect on pro-social and altruistic behaviours. People with religious bonds are reported to contribute more actively to charitable practices (23). In this study, Christians were $56 \%$ less likely to donate blood which might be due to Islamic practice of giving. Study to assess motivation of Iranians who are mainly Muslims showed that religious beliefs are the most frequent positive motivation after altruism for blood donation (24). Also, other reports from Saudi Arabia which is an Islamic nation showed that $71-91 \%$ of donors considered donation as religious ruling $(17,25,26)$.

The index study showed that source of awareness of blood donation being a health worker is a significant predictor of blood donation. This might be due to accuracy of information on blood donation processes given by health workers as a result of their education and work experience. This finding is in contrast to reports of Sharmack et al (27) and Dubey et. (28).

In this investigation, course of study was a significant predictor of blood donation as those who studied health related courses are 3 times likely to donate than those that did not study health science related courses. This is in agreement with reports in Iraq (29) and Nepal (30) as students with health science related background are likely to be more educated and literate about the practices involved in saving human lives.

There is evidence that supports the fact that the more knowledgeable an individual is about the blood donation process and the need for blood, the more likely one is to donate blood $(31,32)$. This study showed that there was significant different in knowledge of donors 
compared with non-donors, as donors had a better knowledge. This is in agreement with reports by Kim et al (33) 36a and Al-Haqqan et al (34).

Limitation: Our data collection instrument depended on self-reported response of the respondents which may be influenced by information bias due to faulty recall. Temporal association of knowledge on blood donation practice cannot be absolutely proven due to the nature of the cross-sectional study design

\section{CONCLUSION}

A large number of the youth had poor knowledge about blood donation and fewer are willing to donate. Education programs and motivational campaigns on importance of blood donation should be intensified in our tertiary institutions. Also, creation of regular blood donation camps may improve voluntary blood donations among youths.

Acknowledgments: The authors would like to thank the youth corp members who agreed to participate in the study.

Conflict of interests: There are no conflicts of interest.

\section{REFERENCES}

1. WHO, Voluntary unpaid blood donations must increase rapidly to meet 2020 goal [Internet], WHO, World Health Organization, 2016, http://www.who.int/mediacentre/news/releases/ 2016/world-blood-donor-day/en/.

2. Van Hulst M, SmitSibinga CT, Postma MJ. Health economics of blood transfusion safety-focus on sub-Saharan Africa. Biologicals. 2010;38(1):53-58.

3. WHO, "Towards $100 \%$ Voluntary Blood Donation A Global Framework for Action," [Internet]. M e 1 b o u rne, 2010 , http://www.who.int/worldblooddonorday/Melbo urneDeclarationWBDD09.pdf.

4. Manikandan S, Srikumar R, Ruvanthika PN. A study of knowledge, attitude and practice on blood donation Health Professional Students in Chennai, Tamil Nadu, South India.IJRSP.2013; (3): $1-4$

5. Syiemlieh AJ, Akoijam BS, Kumar S, Assessment Knowledge, Perception and Practice of Voluntary Blood Donation among Health Professional Students in RIMS, Imphal, Manipur.IOSRJDMS.2016;15(10):26-30

6. Wanitkit, V. Knowledge about Blood Donation among a Sample of Thai University Students. The International Journal of Transfusion Medicine. Vox Sanguinis. 2002; 83: 97-99.

7. Misganaw C, Tenkir M, Deresa A, Tesfaye M,
Tessema TT, Taye H. The level and associated factors of knowledge, attitude and practice on blood donation among health science students in Addis Ababa University. IJMHSR. 2014;1(10):105-18

8. Al-Asadi1 JN, Asaad Q, Al-Yassen. Knowledge, attitude and practice of blood donation among university students in Basrah, Iraq: A comparison between medical and non-medical students. Asian JMed Sci.201;9(6):62-67

9. Salaudeen AG, Odeh E. Knowledge and behavior towards voluntary blood donation among students of a tertiary institution in Nigeria. Niger J Clin Pract 2011; 14:303-307.

10. Jose AP, Angadi MM, Masali KK, Bhat S, Shashank KJ, Wajantri P. Knowledge Attitude and Practices on Voluntary Blood Donation among College Students in Bijapur, Karnataka. IJCRR.2013;5: 26-31.

11. Amatya, M. Study on Knowledge, Attitude and Practice of Blood Donation among Students of Different Colleges of Kathmandu, Nepal. IJPBA.2013;4: 424-428.

12. Elionora E, Wilhellmuss M, Rune NP, Damian JD, Michael JM, Sia EM. Knowledge, Attitudes, Practices, and Factors Associated with Voluntary Blood Donation among University Students in Kilimanjaro, Tanzania. J Blood Transf. $\begin{array}{llllllllllll}2 & 0 & 1 & 6 & : & 8 & 5 & 4 & 6 & 8 & 0 & 3\end{array}$ http://dx.doi.org/10.1155/2016/8546803

13. Sojka BN. and Sojka P. The Blood Donation Experience: Self-Reported Motives for and Obstacles to Donating Blood. Vox Sanguinis.2008; 94: 56-63.

14. Umakanth, S, Tsubaki T, Molly R, Nair S C, Daniel D. A study of perspectives and attitudes towards voluntary blood donation as a step towards improving donor recruitment and retention strategies in a tertiary referral hospital in South India. Asian J Transf Sci.2008;2(1): p34

15. Nwogoh B, Aigberadion U, Nwannadi A. Knowledge, Attitude, and Practice of Voluntary Blood Donation among Healthcare Workers at the University of Benin Teaching Hospital, Benin City, Nigeria. Journal of Blood Transfusion. 2013;10: 115-120

16. Sabu KM, Remya A, Binu VS and Vivek R. Knowledge, Attitude and Practice on Blood Donation among Health Science Students in a University campus, South India. Online J Health A 11 i ed S c s . $2011 ; 10: 6$. U R L : http://www.ojhas.org/issue38/2011-2-6.htm

17. Abolfotouh MA, Al-Assiri MH, Al-Omani M, Al Johar A,Al Hakbani A, Ahmed S Alaskar AS.Public awareness of blood donation in Central Saudi Arabia. Int J Gen Med. 2014; 7: 401-410.

18. Hollingsworth B, Wildman J. What population factors influence the decision to donate blood? Transfus Med. 2004;14(1):9-12.

19. Sojka BN, Sojka P. The blood-donation experience: perceived physical, psychological and social impact of blood donation on the donor. 
Vox Sang. 2003;84(2):120-128.

20. Safizadeh H, Pourdamghan N, Mohamadi B. University Students Awarenessand Attitude towards Blood Donation in Kermen City.IJBC.2019;1(3):107-10

21. Alethea Z,Silveira MF, Dumith SC. Blood Donation Prevalence and Associated factors in Pelotas, South Brazil, \. Rev Saude Publica.2010; 44(1):112-20

22. Burgdorf KS, Simonsen J, Sundby A, Rostgaard K, Pedersen OB, Sørensen E, et al. (2017) Sociodemographic characteristics of Danish blood donors. PLoS ONE 12(2): e0169112. https://doi.org/10.1371/journal.pone.0169112

23. Vassilis S, Pichon I, Trompette L, Verschueren M, Rebecca D. Prosocial Behavior and Religion: New Evidence Based on Projective Measures and Peer Ratings. J Sci Study Relig. 2005;44:323-48.

24. Maghullu M. Assessing the Motivation of Blood Donors in 28 Provinces of Iran.Research Collection of Iranian Blood Transfusion Organization. Iranian Blood Transfusion Research Center Publication. (2nd ed) 2005;2:37.

25. Alfouzan N. Knowledge, Attitudes, and Motivations towards Blood Donation among King Abdulaziz Medical City Population.Int J Family Med. 2014; 2014: 539670doi: $10.1155 / 2014 / 539670$

26. Abdel Gader A. GM, Osman A MA, Al Gahtani FH, Farghali MN, Ramadan A H, Al-Momen AKM. Attitude to blood donation in Saudi Arabia. Asian Journal of Transfusion Science. 2011;5(2):121-126.

27. Sharma RK, Verma S, Sharma M, Pugazhendi S (2016) Voluntary Blood Donation: Attitude and Practice among Indian Adults. J Community Med
Health 3:436. doi:10.4172/2161-0711.1000436

28. Dubey A, Sonker A, Chaurasia R, Chaudhary R. Knowledge, attitude and beliefs of people in North India regarding blood donation. Blood Transfus.2014: 12: s21-s27.

29. Jasim N. Al-Asadi1, Asaad Q. Al-Yassen2. Knowledge, attitude and practice of blood donation among university students in Basrah, Iraq: A comparison between medical and nonmedical students. Asian J Med Sci.2018;9( 6) 10.3126/ajms.v9i6.20904

30. Mamatya A, Prajapati R, Yadav R. Knowledge and Practice of blood donation: a comparison between medical and nonmedical Nepalese students. Nep Med Coll J. 2012;14:283-286.

31. Buciuniene I, Stoniene L, Blazeviciene A, Kazlauskaite R, Skudiene V. Blood donors' motivation and attitude to non-remunerated blood donation in Lithuania. BMC Public Health. 2006;6:166.

32. 18. 32Godin G, Sheeran P, Conner M, et al. Factors explaining the intention to give blood among the general population. Vox Sang. 2005;89(3):140-149.

33. Kim JH, Yoon JS. Association between Knowledge, Attitude, and Practice Regarding Blood Donation in University Students. The Journal of the Korea Contents Association. 2015;15(10):316-26

34. Al-Haqqan T, Husain A, Al-Kandari N, AlRashidi L, Al-Daihani N, et al.A Cross-Sectional Study of Knowledge, Attitude, Practice, and BarriersRegarding Blood Donation among General Population in Kuwait. Int J CommunityFam Med. 2016; 1: 120. doi: https://doi.org/10.15344/2456-3498/2016/120 
Table 1: Knowledge of blood donation among the respondents

\begin{tabular}{lcc}
\hline Variable & $\begin{array}{c}\text { Frequency } \\
\mathbf{n = 5 3 5}\end{array}$ & Percent \\
\hline Importance of blood donation* & & \\
Blood loss & 477 & 89.2 \\
Surgery & 403 & 75.3 \\
Sickle cell disease & 351 & 65.5 \\
Cancer & 331 & 61.9 \\
Blood volume donate /time & & \\
450mls & 57 & 10.7 \\
Duration of a donation process & & \\
Less than 20minutes & 133 & 24.9 \\
Who should donate* & & \\
Men & 258 & 48.2 \\
Women & 144 & 26.9 \\
Donation frequency & & \\
3-4times/year & 49 & 9.2 \\
TTIs* & & \\
HIV & 476 & 91.9 \\
HBV & 173 & 33.4 \\
HCV & 101 & 19.5 \\
Syphilis & 65 & 12.5 \\
Malaria & 48 & \\
& & \\
\hline Wrong responses are not shown in the table & \\
TTIs =Transfusion transmissible infections, & \\
$*$ multiple responses are allowed, & & \\
HIV= Human Immunodeficiency Virus, & \\
HBV= Hepatitis B Virus, HCV= Hepatitis C Virus & \\
&
\end{tabular}

Table 2: Association of socio-demographic characteristics and medium of information with knowledge of the respondents

\begin{tabular}{|c|c|c|c|c|c|}
\hline \multirow[t]{2}{*}{ Variables } & \multicolumn{2}{|c|}{$\begin{array}{l}\text { Knowledge }(\mathrm{n}=535) \\
\mathrm{n}(\%)\end{array}$} & \multirow[t]{2}{*}{ Total } & \multirow[t]{2}{*}{$\mathrm{X}^{2}$} & \multirow[t]{2}{*}{ P-value } \\
\hline & Poor & Good & & & \\
\hline \multicolumn{6}{|l|}{ Age Group (Years) } \\
\hline$=24$ & $123(50 \%)$ & $123(50 \%)$ & $246(100 \%)$ & 13.568 & 0.000 \\
\hline$>24$ & $190(65.7 \%)$ & $99(34.3 \%)$ & $289(100 \%)$ & & \\
\hline \multicolumn{6}{|l|}{ Sex } \\
\hline Male & $169(61.2 \%)$ & $107(38.8 \%)$ & $276(100 \%)$ & 1.747 & 0.109 \\
\hline Female & $144(55.6 \%)$ & $115(44.4 \%)$ & $259(100 \%)$ & & \\
\hline \multicolumn{6}{|l|}{ Marital Status } \\
\hline Single & $306(58.7 \%)$ & $215(48.7 \%)$ & $521(100 \%)$ & 0.428 & 0.348 \\
\hline Married & $7(50 \%)$ & $7(50 \%)$ & $14(100 \%)$ & & \\
\hline \multicolumn{6}{|l|}{ Religion } \\
\hline Christian & $261(57.6 \%)$ & $192(42.4 \%)$ & $453(100 \%)$ & 0.962 & 0.196 \\
\hline Muslim & $52(63.4 \%)$ & $30(36.6)$ & $82(100 \%)$ & & \\
\hline \multicolumn{6}{|l|}{ Course of study } \\
\hline Health Sciences & $7(15.6 \%)$ & $38(84.4)$ & $45(100)$ & 37.333 & 0.000 \\
\hline Non-Health Sciences & $306(62.4)$ & $184(37.6)$ & $490(100)$ & & \\
\hline \multicolumn{6}{|c|}{$\begin{array}{l}\text { Medium of awareness of } \\
\text { blood donation }\end{array}$} \\
\hline Health workers & $149(62.6)$ & $89(37.4)$ & $238(100)$ & 2.969 & 0.051 \\
\hline Others & $164(55.2)$ & $133(44.8)$ & $297(100)$ & & \\
\hline
\end{tabular}


Table 3: Association of socio-demographic characteristics and medium of information with donation pattern of the respondents

\begin{tabular}{|c|c|c|c|c|c|}
\hline \multirow[t]{2}{*}{ Variables } & \multicolumn{2}{|c|}{$\begin{array}{l}\text { Donation }(\mathrm{n}=535) \\
\mathrm{n}(\%)\end{array}$} & \multirow[t]{2}{*}{ Total } & \multirow[t]{3}{*}{$\mathrm{X}^{2}$} & \multirow[t]{2}{*}{ P-value } \\
\hline & Yes & No & & & \\
\hline \multicolumn{5}{|l|}{ Age Group (Years) } & \\
\hline$=24$ & $33(13.4 \%)$ & $213(86.6 \%)$ & $246(100 \%)$ & 3.407 & 0.041 \\
\hline$>24$ & $56(19.4 \%)$ & $233(80.6 \%)$ & $289(100 \%)$ & & \\
\hline \multicolumn{6}{|l|}{ Sex } \\
\hline Male & $62(22.5 \%)$ & $214(77.5 \%)$ & $276(100 \%)$ & 13.964 & 0.000 \\
\hline Female & $27(10.4 \%)$ & $332(89.6 \%)$ & $259(100 \%)$ & & \\
\hline \multicolumn{6}{|l|}{ Marital Status } \\
\hline Single & $81(15.5 \%)$ & $440(84.5 \%)$ & $521(100 \%)$ & 17.010 & 0.001 \\
\hline Married & $8(57.1 \%)$ & $6(42.9 \%)$ & $14(100 \%)$ & & \\
\hline \multicolumn{6}{|l|}{ Religion } \\
\hline Christian & $63(13.9 \%)$ & $390(86.1 \%)$ & $453(100 \%)$ & 15.863 & 0.000 \\
\hline Muslim & $26(63.4 \%)$ & $56(36.6)$ & $82(100 \%)$ & & \\
\hline \multicolumn{6}{|l|}{ Course of study } \\
\hline Health Sciences & $16(35.6 \%)$ & $29(64.4)$ & $45(100)$ & 12.682 & 0.001 \\
\hline Non-Health Sciences & $73(14.9)$ & $417(85.1)$ & $490(100)$ & & \\
\hline \multicolumn{6}{|c|}{$\begin{array}{l}\text { Medium of awareness of } \\
\text { blood donation }\end{array}$} \\
\hline Healthworkers & $50(21)$ & $188(79)$ & $238(100)$ & 5.911 & 0.010 \\
\hline Others & $39(13.1)$ & $258(86.9)$ & & & \\
\hline
\end{tabular}

Table 4: Logistic regression analysis of socio-demographic characteristics and medium of information on knowledge of the respondents

\begin{tabular}{|c|c|c|c|c|c|}
\hline \multirow[t]{2}{*}{ Variable } & \multirow[t]{2}{*}{ B } & \multirow[t]{2}{*}{ OR } & \multirow[t]{2}{*}{$P$ value } & \multicolumn{2}{|c|}{$95 \% \mathrm{CI}$} \\
\hline & & & & Lower & Upper \\
\hline \multicolumn{6}{|l|}{ Age Group (Years) } \\
\hline$>24$ & Ref & & & & \\
\hline$=24$ & 0.713 & 2.040 & 0.000 & 1.404 & 2.966 \\
\hline \multicolumn{6}{|l|}{ Sex } \\
\hline Female & Ref & & & & \\
\hline Male & -0.015 & 0.985 & 0.938 & 0.676 & 1.435 \\
\hline \multicolumn{6}{|l|}{ Religion } \\
\hline Muslim & Ref & & & & \\
\hline Christian & 0.156 & 1.169 & 0.557 & 0.694 & 1.969 \\
\hline \multicolumn{6}{|l|}{ Course of study } \\
\hline Non-Health Sciences & Ref & & & & \\
\hline Health Sciences & 2.314 & 10.116 & 0.000 & 4.368 & 23.427 \\
\hline \multicolumn{6}{|c|}{$\begin{array}{l}\text { Medium of awareness of } \\
\text { blood donation }\end{array}$} \\
\hline Others & Ref & & & & \\
\hline Health workers & -0.243 & 0.784 & 0.199 & 0.784 & 1.136 \\
\hline
\end{tabular}


Table 5: Logistic regression analysis of socio-demographic characteristics and medium of information on donation pattern of the respondents

\begin{tabular}{|c|c|c|c|c|c|}
\hline \multirow[t]{2}{*}{ Variable } & \multirow[t]{2}{*}{ B } & \multirow[t]{2}{*}{ OR } & \multirow[t]{2}{*}{$\mathrm{P}$ value } & \multicolumn{2}{|l|}{$95 \% \mathrm{CI}$} \\
\hline & & & & Lower & Upper \\
\hline \multicolumn{6}{|l|}{ Age Group (Years) } \\
\hline$>24$ & Ref & & & & \\
\hline$=24$ & -0.283 & 0.745 & 0.282 & 0.450 & 1.262 \\
\hline \multicolumn{6}{|l|}{ Sex } \\
\hline Female & Ref & & & & \\
\hline Male & 0.835 & 2.204 & 0.002 & 1.352 & 3.926 \\
\hline \multicolumn{6}{|l|}{ Marital Status } \\
\hline Married & Ref & & & & \\
\hline Single & -1.571 & 0.208 & 0.011 & 0.062 & 0.695 \\
\hline \multicolumn{6}{|l|}{ Religion } \\
\hline Muslim & Ref & & & & \\
\hline Christian & -0.875 & 0.417 & 0.003 & 0.233 & 0.746 \\
\hline \multicolumn{6}{|l|}{ Course of study } \\
\hline Non-Health Sciences & Ref & & & & \\
\hline Health Sciences & 1.104 & 2.755 & 0.008 & 1.306 & 5.814 \\
\hline \multicolumn{6}{|c|}{$\begin{array}{l}\text { Medium of awareness of } \\
\text { blood donation }\end{array}$} \\
\hline Others & Ref & & & & 2.395 \\
\hline Health workers & 0.514 & 1.672 & 0.039 & 1.026 & 2.725 \\
\hline
\end{tabular}

Ref: reference variable 